\title{
Agronomic, morphogenic and structural characteristics of Marandu grass in silvopastoral systems composed of babassu palm and grass monoculture
}

\section{Características agronômicas, morfogênicas e estruturais do capim- Marandu em sistemas silvipastoris formados por palmeiras de babaçu e em monocultura}

\author{
Rosane Cláudia Rodrigues ${ }^{1 *}$; Antonio José Temístocles de Lima²; \\ Ricardo Alves de Araújo ${ }^{3}$; Ana Paula Ribeiro de Jesus ${ }^{1}$; Clésio Dos Santos Costa \\ Francisco Naysson Sousa Santos ${ }^{5}$; Francivaldo Oliveira Costa \\ José Antônio Alves Cutrim Júnior ${ }^{6}$; Francirose Shigaki ${ }^{1}$; \\ Danielle Maria Machado Ribeiro Azevêdo ${ }^{7}$
}

\begin{abstract}
This study evaluated the agronomic, morphogenic and structural characteristics of palisadegrass (Urochloa brizantha) in silvopastoral systems (SSP's) composed of babassu palms (Attalea speciosa) and grass monoculture in the Pre-Amazon region of the state of Maranhão, Brazil. The study followed a completely randomized design, with the arrangement in split plots with six replicates for the evaluation of agronomic characteristics and 30 repetitions for the morphogenic and structural characteristics. The plots were divided into pasture environments with different palm densities (monoculture, 80, 131, 160 palms.ha ${ }^{-1}$ ), and the subplots were divided into the different seasons (rainy and dry). Total forage production was affected $(\mathrm{P}<0.05)$ by the interaction between palm density and season. The rainy season, compared to the dry season, presented higher total forage production, whereas among silvopastoral systems, the one with 80 palms.ha- ${ }^{1}$ presented higher production. The same pattern was found for leaf production. In the rainy season the production of culms increased, as did the ratio leaf.culm ${ }^{-1}$. Regarding the accumulation of dead material, the only observed difference was a smaller accumulation in the dry season for pastures with 160 palms.ha- ${ }^{1}$. In the rainy season, the leaf elongation rate, leaf appearance rate, and final leaf length had higher values in the silvopastoral system with 131 palm.ha ${ }^{-1}$, whereas during the dry season, these variables only differed in the monoculture system. Tiller elongation rate and the phyllochron were not affected $(\mathrm{P}>0.05)$ by pastoral system during the rainy season, but in the dry period, higher responses were obtained in SSPs. Overall, SSPs with 80 palms.ha $^{-1}$ favored the agronomic characteristics of pastures. Morphogenic and structural characteristics were favored by increasing palm
\end{abstract}

\footnotetext{
${ }^{1}$ Profs., Universidade Federal do Maranhão, UFMA, Chapadinha, MA, Brasil. E-mail: rosanerodrig@gmail.com; btanapaula@ hotmail.com; francirose@yahoo.com.br

2 Zootecnista, Mestre em Ciência Animal, Chapadinha, MA, Brasil. E-mail: aj_tinho@hotmail.com

3 Discente do Curso de Doutorado do Programa de Pós-Graduação Integrado em Zootecnia, Departamento de Zootecnia, UFC/ UFRPE/UFPB, Fortaleza, CE, Brasil. E-mail: ricardo_zoo@hotmail.com

${ }^{4}$ Discentes do Curso de Mestrado do Programa de Pós-Graduação em Ciência Animal, UFMA, Chapadinha, MA, Brasil. E-mail: clesiosantzoo@gmail.com; francivaldo.oliveira@hotmail.com

5 Discente do Curso de Mestrado do Programa de Pós-Graduação em Zootecnia, UFC, Departamento de Zootecnia, Fortaleza, CE, Brasil. E-mail: nayssonzootecnista@gmail.com

${ }^{6}$ Prof., Instituto Federal do Maranhão, IFMA, São Luis, MA, Brasil. E-mail: cutrimjunior@gmail.com

7 Pesquisadora da Embrapa Meio-Norte, Teresina, PI, Brasil. E-mail: danielle.azevedo@embrapa.br

* Author of correspondence
} 
densities. Leaf senescence and duration were not affected by the system.

Key words: Attalea speciosa. Urochloa brizantha. Densities. Phyllochron. Morphogenesis. Rate of leaf appearance.

\section{Resumo}

Objetivou-se avaliar as características agronômicas, morfogênicas e estruturais do capim-Marandu (Urochloa brizantha) em sistemas silvipastoris (SSP's) compostos por palmeiras de babaçu (Attalea speciosa) e em monocultivo de capim-Marandu na região Pré-Amazônica Maranhense. O delineamento experimental adotado foi o inteiramente casualizado, com o arranjo em parcelas subdivididas com seis repetições para a avaliação das características agronômicas e 30 repetições para as características morfogênicas e estruturais. As parcelas foram constituídas pelos ambientes pastoris e suas densidades (monocultura, 80, 131, 160 palmeiras.ha ${ }^{-1}$ ) e nas subparcelas os períodos (chuvoso e seco). A produção total de forragem foi influenciada $(\mathrm{P}<0,05)$ pela interação densidades $\mathrm{x}$ épocas do ano. Entre as épocas, o período chuvoso foi o que apresentou maior produção total de forragem e entre os ambientes pastoris a densidade de 80 palmeiras.ha ${ }^{-1}$ apresentou maior produção. A mesma resposta foi encontrada para a produção de folhas. No período chuvoso foi observado maior produção de colmos e relação folha. colmo $^{-1}$. Para o acúmulo de material morto só houve efeito $(\mathrm{P}<0,05)$ entre os períodos, onde pastagens com 160 palmeiras.ha ${ }^{-1}$, no período seco tiveram menor acúmulo. No período chuvoso, as taxas de alongamento foliar, aparecimento foliar, e comprimento final da folha tiveram maiores valores no ambiente pastoril com 131 palmeiras.ha ${ }^{-1}$, enquanto no período da seca, essas características diferiram $(\mathrm{P}<0,05)$ somente em relação a monocultura. A taxa de alongamento do colmo e o filocrono não foram influenciados $(\mathrm{P}>0,05)$ pelos ambientes pastoris no período chuvoso, no entanto no período da seca, as maiores respostas foram obtidas nos SSP's. O sistema silvipastoril com 80 palmeiras.ha- ${ }^{-1}$ favorece as características agronômicas da pastagem. Já as características morfogênicas e estruturais são favorecidas com o aumento da densidade de palmeiras nas pastagens. As características taxa de senescência foliar e duração de vidas das folhas não são afetadas pela densidade de palmeiras nas pastagens e/ou monocultura.

Palavras-chave: Attalea speciosa. Urochloa brizantha. Densidades. Filocrono. Morfogênese. Taxa de aparecimento foliar.

\section{Introduction}

The development of sustainable production systems represents one of the largest challenges faced by the cattle industry today. The use of silvopastoral areas may provide an option for the production of high-quality beef with lower environmental impact. These areas combine, intentionally or by chance, trees, pastures and animals in the same period of time, during which an integrated management approach aims at increasing productivity per unit area (EMBRAPA, 2013).

Usually, the intentional creation of silvopastoral systems makes use of domesticated tree species, in detriment of wild species such as the babassu palm (Attalea speciosa), seen only as a target for the extractive industry. Thus, despite their importance to the local economy, little is known about the ecological properties of babassu palms, or about their contribution to animal production and pasture management at different palm densities.

Babassu plantations reduce the amount of sunlight available to plants growing under the canopy, and affect morphophysiological aspects that determine pasture productivity. Paciullo et al. (2007) observed an increase in specific leaf area and a decrease in the leaf area index of $B$. decumbens pastures grown under shaded conditions in comparison to pastures grown under the open sunlight. A deep understanding of the morphological adaptations of grasses to environments with low light incidence represents a crucial step for the 
development of efficient management strategies aimed at silvopastoral areas, and at the long-term equilibrium of these ecosystems.

Starting from the knowledge that the natural shades provided by babassu plantations affect the growth and development of grasses, the present work evaluated the agronomic, morphogenic and structural characteristics of palisadegrass monocultures kept under three babassu-palm densities.

\section{Materials and Methods}

Experiments were conducted at the ÁguaViva farm, in the municipality of Matinha, in the region of Baixada Maranhense, state of Maranhão,

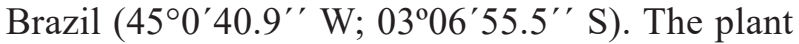
species used were the palisadegrass Urochloa brizantha and the babassu palm Attalea speciosa Martius, both of which were already established at the experimental site. Grass characteristics were evaluated under four conditions including palisadegrass monoculture and palisade grass in combination with three different palm tree densities $\left(80,131,160\right.$ palms.ha $\left.{ }^{-1}\right)$.

Figure 1 displays the average rainfall calculated from a 30-year series and during the experimental period. During the study period, the rainfall averaged 2,000 $\mathrm{mm}$ per year, with higher concentration in the months of April to June. Maximum and minimum temperatures ranged between $32^{\circ}$ and $23^{\circ} \mathrm{C}$, respectively (INMET, 2013).

Figure 1. Average temperatures during the study period and average monthly rainfall calculated from a 30-year series and from the experimental period.

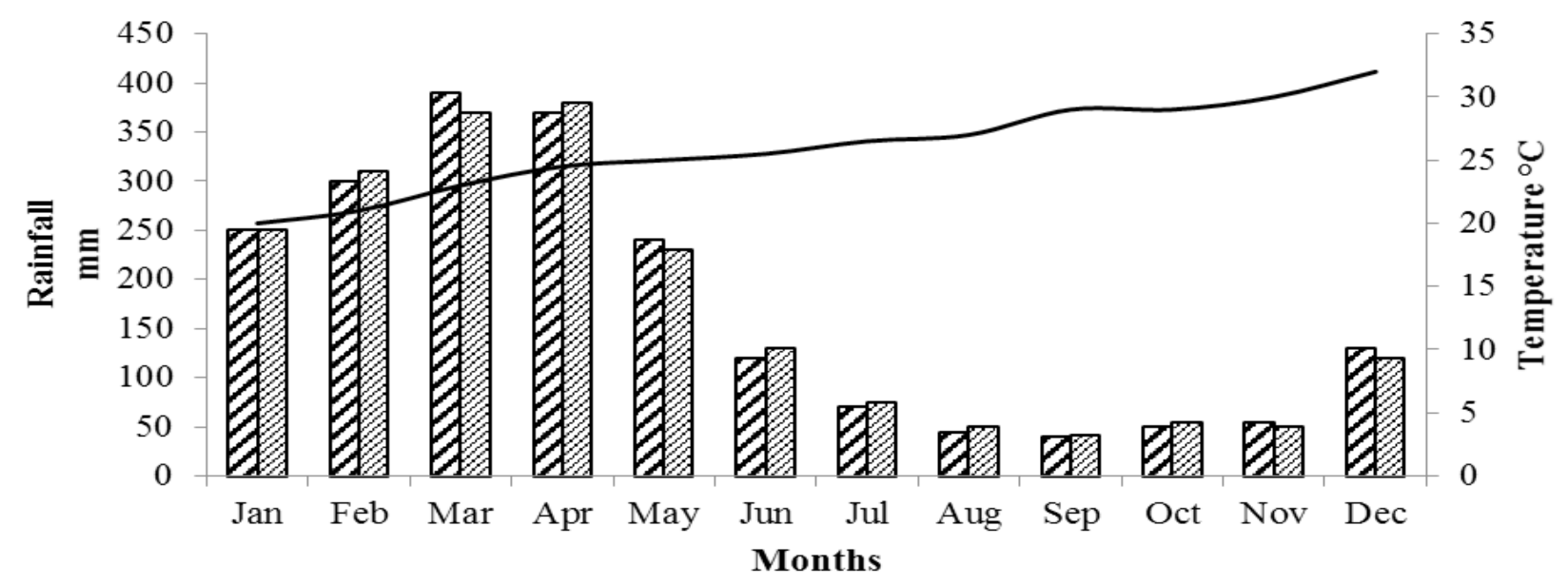

שPrecipitation 30 years ש Precipitation 2013 - temperature

The total experimental area measured eight hectares, subdivided into four two-hectare plots, managed under continuous grazing, with five mixed Nelore x Guzerá animals weighing, on average, $180 \pm 15 \mathrm{~kg}$, in each unit. Animals were added or removed from the units as required to keep the pasture at the pre-determined height of $35 \mathrm{~cm}$. When not in the experimental units, animals were kept in a reserved six-hectare area. All animals received water and mineral mixture ad libitum, as well as the recommended sanitary management (EMBRAPA, 2011).

Before initiating the experiment, we took samples and assessed soil fertility in the $0-20 \mathrm{~cm}$ 
layer. As shown in Table 1, all experimental units had medium soil fertility, and, regardless of treatment, soil acidity was corrected through the elevation of base saturation to $70 \%$. Area preparation and these corrective measures were conducted from October to November of 2011. Between January and February of 2012, new grass was planted in areas where the soil was exposed.
The experimental units were fertilized with nitrogen $(\mathrm{N})$ in the form of urea at 150 kg.ha' ${ }^{-1}$, phosphorus $\left(\mathrm{P}_{2} \mathrm{O}_{5}\right)$ in the form of simple superphosphate at $150 \mathrm{~kg} \cdot \mathrm{ha}^{-1}$, and potassium chloride $(\mathrm{KCl})$ at $60 \mathrm{~kg} \cdot \mathrm{ha}^{-1}$. Finally, depending on the silvopastoral system, dolomitic lime was added at $550,135,775$ and $630 \mathrm{~kg} \cdot \mathrm{ha}^{-1}$ to the palisadegrass monoculture and the three increasing palm-tree densities (80, 131 e 160 palms.ha $\left.^{-1}\right)$, respectively.

Table 1. Soil chemical composition prior to the beginning of experiments in the four pasture systems evaluated.

\begin{tabular}{|c|c|c|c|c|c|c|c|c|c|c|}
\hline \multirow{2}{*}{$\begin{array}{l}\text { Palm densities } \\
\text { palms.ha- }^{1}\end{array}$} & \multirow{2}{*}{$\begin{array}{c}\mathrm{pH} \\
\mathrm{CaCl}_{2}\end{array}$} & M.O & $\mathrm{P}$ & K & $\mathrm{Ca}$ & $\mathrm{Mg}$ & $\mathrm{H}+\mathrm{Al}$ & $\mathrm{Al}$ & B & CTC \\
\hline & & \multicolumn{4}{|c|}{-------g dm ${ }^{3-(1)}$} & \multicolumn{5}{|c|}{ - $\mathrm{mmol}_{\mathrm{c}} \mathrm{dm}^{3-(1)}$} \\
\hline Monoculture & 4.8 & 23 & 21 & 32 & 17 & 6 & 42 & 2 & 19 & 68 \\
\hline 80 & 5.2 & 23 & 9 & 40 & 21 & 9 & 27 & 1 & 20 & 61 \\
\hline 131 & 5.0 & 22 & 23 & 26 & 22 & 10 & 42 & 2 & 20 & 77 \\
\hline 160 & 4.8 & 23 & 11 & 37 & 20 & 7 & 44 & 1 & 28 & 75 \\
\hline \multirow{2}{*}{$\begin{array}{l}\text { Palm densities } \\
\text { palms.ha- }^{1}\end{array}$} & \multicolumn{2}{|c|}{$\mathrm{V}$} & $\mathrm{S}$ & \multicolumn{2}{|c|}{$\mathrm{Cu}$} & $\mathrm{Fe}$ & $\mathrm{Zn}$ & \multicolumn{2}{|c|}{ Mn } & B \\
\hline & \multicolumn{2}{|c|}{----- \% ----- } & & & 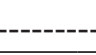 & \multicolumn{2}{|c|}{$\mathrm{mg} \mathrm{dm}^{3-(1)}$} & & & --- \\
\hline Monoculture & \multicolumn{2}{|c|}{38} & 5 & \multicolumn{2}{|c|}{0.4} & 104 & 4.4 & \multicolumn{2}{|c|}{47.3} & 0.19 \\
\hline 80 & \multicolumn{2}{|c|}{56} & 7 & \multicolumn{2}{|c|}{0.4} & 149 & 4.2 & \multicolumn{2}{|c|}{33.6} & 0.20 \\
\hline 131 & \multicolumn{2}{|c|}{45} & 6 & \multicolumn{2}{|c|}{0.4} & 61 & 4.6 & \multicolumn{2}{|c|}{54} & 0.20 \\
\hline 160 & \multicolumn{2}{|c|}{41} & 10 & \multicolumn{2}{|c|}{0.4} & 105 & 4.1 & \multicolumn{2}{|c|}{44} & 0.28 \\
\hline
\end{tabular}

Grass canopy height was measured weekly, with a graduated ruler marked in centimeters, in 30 random points within each experimental unit.

Forage mass evaluations were conducted every 28 days. To estimate forage productivity (FP) representative samples were collected from each unit. Metallic squares measuring $0.25 \mathrm{~m}^{2}$ were randomly thrown on representative pasture areas, all the plants in the interior of the squares were cut close to the ground and collected. Samples were weighed and then separated into morphological components including leaves, culm and dead material. Samples were oven-dried at $65^{\circ} \mathrm{C}$ until a constant mass was obtained, when the proportion of each component was weighed and expressed as a percentage of total weight. Based on these results, the leaf.culm ${ }^{-1}$ ratio (LCR) was estimated.
To determine total forage production (TFP), leaf production (LP), culm production (CP), accumulation of dead material (ADM) and the leaf to culm ratio (LCR), we collected six representative samples per hectare using the same $0.25 \mathrm{~m}^{2}$ metallic squares, every 28 days. The squares were thrown over representative pasture areas, i.e., in shaded areas, near the base of the palms, and in areas under direct sunlight. All the plants inside the frame were cut at a height of $10 \mathrm{~cm}$ from the soil, within grazing conditions.

Tissue flow was measured with the help of a graduated ruler marked in millimeters. Thirty vegetation tillers were chosen within each unit and marked with colored tapes and wooden stakes to facilitate locating them. At these points, once per week, we measured leaf blades, green and 
senescent parts, and, from these data, we estimated morphogenic growth and senescence indexes.

The morphogenic variables include rate of leaf appearance (RLA), obtained from the number of new leaves growing in the marked tillers, divided by the number of days since the last evaluation; phyllochron (PHY); leaf elongation rate (LER) estimated from the difference between final and initial length of leaves, divided by the number of days since the last evaluation; tiller elongation rate (TER) estimated from the difference between final and initial length of culms, divided by the number of days since the last evaluation; leaf senescence rate, estimated from the senescent area in the marked tillers which provided the accumulation of dead material that was divided by the number of days since the last evaluation, as per the methodology described by Chapman and Lemaire (1993).

Structural characteristics include final leaf length (FLL), defined as the distance between leaf apex and ligule of each leaf in the tiller; and leaf duration (LD) which corresponds to the time the leaf remained alive after complete exposure of the ligule. Leaves were considered dead when more than $50 \%$ of the leaf area was yellowish.

Data were initially submitted to the normality (Crame-Von Misses) and homoscedasticity tests and, when premises were met, data were submitted to analysis of variance with the $\mathrm{F}$ test. When significant differences existed, averages were compared by Duncan's test with $5 \%$ probability. Statistical analyses were conducted with the software InfoStat ${ }^{\circledR}$ (INFOSTAT, 2004).

\section{Results and Discussion}

An interaction between palm-tree density and season affected TLP. During the rainy season there was an increase in leaf production. During the dry season, TLP was not different between the palisadegrass monoculture and the silvopastoral system with 131 palms.ha-1 (Table 2). Use of $\mathrm{N}$ as a fertilizer had a direct effect on TLP, owing to an increase in photosynthesizing leaf area. This finding highlights the importance of $\mathrm{N}$ in forage production. Because fertilization was performed in a single plot, results were not very expressive. Nevertheless, our results corroborate those of other authors who investigated the effects of $\mathrm{N}$ on $\mathrm{C} 4$ grass production (CAMINHA et al., 2010; ALEXANDRINO et al., 2010).

During the rainy season, the silvopastoral system with 80 palms.ha-1 ${ }^{-1}$ yielded the highest TLP, even though statistically TLP was the same as observed under monoculture, the latter displayed a $18.75 \%$ reduction in TLP during the rainy season. TLP levels in the systems with 131 and 160 palms.ha-1 were not significantly different between them, but, when compared to the system with 80 palms.ha' ${ }^{1}$, TLP levels were lower by $22,70 \%$ and $24,20 \%$, respectively.

During the dry season, pastures with palisadegrass only and with 80 palms.ha- ${ }^{-1}$ had the same level of TLP, pastures with 131 palms.ha ${ }^{-1}$ had similar, albeit lower TLP levels by 21.42 and $22.80 \%$, respectively. The pasture with 160 palms.ha $^{-1}$ had the lowest TLP during the dry season, comparatively $31 \%, 25 \%$ e $32,45 \%$ lower than the monoculture, and systems with 80 and 131 palms.ha $^{-1}$, respectively.

Seasons only affected culm production in the monoculture system, which displayed $21.37 \%$ lower share of culms in the rainy season in comparison with the dry season $(\mathrm{P}<0.05)$. Palm density had no effect on TCP in the rainy season. In the dry season, the monoculture and the system with 80 palms.ha-1 had higher TCP than the other two systems. The TCP in the system with 131 palms.ha $^{-1}$ was not significantly different from the one with 80 palms. $\mathrm{ha}^{-1}$, although numerically the level was $27.45 \%$ lower.

Culm share was the same in the systems with 160 and 131 palms.ha $^{-1}$, but culm production was $5.40 \%$ lower in the former. According to Cândido et al. (2005), an increase in the share of culm contributes 
to the increase in total forage biomass. However, this change can affect ruminant consumption and performance, because this fraction has more fibers and lower nutritional value. After successive grazing cycles, the culm fraction tends to increase, thus reducing the ratio leaf.culm ${ }^{-1}$.

Table 2. Agronomic characteristics of palisadegrass grown in monoculture or in combination with different densities of babassu palm.

\begin{tabular}{|c|c|c|c|}
\hline \multirow{3}{*}{$\begin{array}{l}\text { Palm density } \\
\text { palm.ha }{ }^{-1}\end{array}$} & \multicolumn{2}{|c|}{ Total forage production (ton of DM.ha' ${ }^{-1}$ ) } & \multirow{3}{*}{$\mathrm{CV}(\%)$} \\
\hline & \multicolumn{2}{|c|}{ Season } & \\
\hline & Rainy & Dry & \\
\hline monoculture & $4.34 \mathrm{Aab}$ & $4.48 \mathrm{Aa}$ & \multirow{4}{*}{11.63} \\
\hline 80 & $5.33 \mathrm{Aa}$ & $4.56 \mathrm{Ba}$ & \\
\hline 131 & $4.12 \mathrm{Ab}$ & $3.52 \mathrm{Aab}$ & \\
\hline 160 & $4.04 \mathrm{Ab}$ & $3.08 \mathrm{Bb}$ & \\
\hline \multicolumn{4}{|c|}{ Leaves (ton of DM. ha- ${ }^{-1}$ ) } \\
\hline monoculture & $1.79 \mathrm{Ab}$ & $1.36 \mathrm{Bab}$ & \multirow{4}{*}{14.17} \\
\hline 80 & 2.49Aa & $1.76 \mathrm{Ba}$ & \\
\hline 131 & $1.73 \mathrm{Ab}$ & $1.40 \mathrm{Bab}$ & \\
\hline 160 & $1.63 \mathrm{Ab}$ & $1.16 \mathrm{Bb}$ & \\
\hline \multicolumn{4}{|c|}{ Culms (ton of DM.ha' $\left.{ }^{-1}\right)$} \\
\hline monoculture & $1.95 \mathrm{Ba}$ & $2.48 \mathrm{Aa}$ & \multirow{4}{*}{11.76} \\
\hline 80 & 2.26Aa & 2.04Aab & \\
\hline 131 & $1.62 \mathrm{Aa}$ & $1.48 \mathrm{Abc}$ & \\
\hline 160 & $1.63 \mathrm{Aa}$ & $1.40 \mathrm{Ac}$ & \\
\hline \multicolumn{4}{|c|}{ Leaf: Culm Ratio } \\
\hline monoculture & $1.23 \mathrm{Aa}$ & $0.56 \mathrm{Bb}$ & \multirow{4}{*}{15.56} \\
\hline 80 & 0.99Aa & $0.87 \mathrm{Aab}$ & \\
\hline 131 & $1.22 \mathrm{Aa}$ & $0.93 \mathrm{Ba}$ & \\
\hline 160 & $1.13 \mathrm{Aa}$ & $0.86 \mathrm{Bab}$ & \\
\hline \multicolumn{4}{|c|}{ Accumulation of dead material (ton of DM.ha' ${ }^{-1}$ ) } \\
\hline monoculture & $0.60 \mathrm{Aa}$ & $0.64 \mathrm{Aa}$ & \multirow{4}{*}{20.91} \\
\hline 80 & $0.77 \mathrm{Aa}$ & $0.66 \mathrm{Aa}$ & \\
\hline 131 & $0.77 \mathrm{Aa}$ & $0.64 \mathrm{Aa}$ & \\
\hline 160 & $0.73 \mathrm{Aa}$ & $0.43 \mathrm{Ba}$ & \\
\hline
\end{tabular}

Means followed by the same uppercase/lowercase letters are not significantly different when in the same line/same column respectively, according to Duncan's test $(\mathrm{P}<0.05)$.

In general, larger productions of forage and a larger share of the leaf and culm fractions were observed in the system with 80 palms.ha ${ }^{-1}$, indicating that, despite having a canopy architecture that favors the passage of light, at higher densities the babassu palm reduces irradiation to levels that affect forage production. According to Rodrigues et al. (2014), shading in silvopastoral systems reduces irradiation and changes the spectrum of light (red:extreme red) reaching the grass canopy in Urochloa decumbens pastures. These changes may decrease temperatures, increasing air humidity, reducing evapotranspiration and increasing soil humidity (FELDHAKE, 2001). Altogether, these microclimatic alterations, may 
have significant effects on grass morphophysiology, which in turn affect the amount and quality of forage produced.

The reduction in culm production with increasing palm density contrasts with previous results showing that an increase in arboreal cover, usually, results in the elongation of culms as grass leaves must compete for a more limited amount of light. In our experiment, babassu palms were considered fully mature with a shaft height of $7.5 \mathrm{~m}$, which did not impede the penetration of diffuse light on the pasture. Moreover, at our location, near the equator, shaded areas move relatively quickly reducing the amount of time any given patch of pasture remains with limited photosynthetic potential.

There was an effect of season on the ratio leaf. culm $^{-1}(\mathrm{P}<0.05)$. In the rainy season there was an increase in the ratio, except in the silvopastoral system with 80 palms.ha $^{-1}$, where no change with seasons was observed $(\mathrm{P}>0.05)$. In the rainy season there was no effect of palm density on the ratio leaf. culm $^{-1}(\mathrm{P}>0.05)$. In the dry season, the system with 131 palms.ha-1 had the highest ratio, the other two palm densities had intermediate values, and the monoculture displayed the lowest ratio. Thus, the shade provided by babassu plantations only had na observable effect on leaf to culm ratio during the dry season. This finding may result from the reduction in hydric deficit caused by elevated temperatures during this period, which increase evapotranspiration and interfere with grass morphological components. Sousa et al. (2010) found an even stronger effect of mastic trees on palisadegrass during the dry season, with ratios of 1.36 and 2.79 for the monoculture and the silvopastoral system, respectively.

Palm densities had no effect on ADM in either season $(\mathrm{P}>0.05)$. However, when making comparisons across seasons, the system with 160 palms.ha ${ }^{-1}$, differently from the other systems, had higher ADM in the rainy season in comparison with the dry season. A reduction in the accumulation of dead tissue results from the reduced growth rates observed among plants grown under reduced irradiation and different microclimatic conditions that include lower temperatures, higher relative air humidity, and higher soil humidity. This pattern was also observed by Pereira et al. (2015) who studied Urochloa decumbens grown in shaded areas.

During the rainy season, the LAR was higher in the system with 131 palms.ha $^{-1}$, and similar among the remaining systems. During the dry season, only the monoculture diverged from the other systems displaying a lower LAR (Table 3). The LAR is a genotypic trait that can be affected by environmental factors. In this case, the silvopastoral systems induced LAR in comparison with grass monoculture, in the rainy and dry seasons.

According to Lemaire and Chapman (1996), LAR deserves the most attention among morphogenic characteristics, because it directly affects the three structural characteristics of grasses: leaf size, population density of tillers, and number of leaves per tiller. The growth rate of grasses depends, predominantly, on the elongation and appearance of leaves and tillers, which were positively affected by the babassu palm in the present study. No differences between seasons could be observed.

Season change affected phyllochron $(\mathrm{P}<0.05)$, only in the monoculture system. When palisadegrass was the only culture, the time between the appearance of two consecutive leaves increased by $33.77 \%$ in the dry period compared to the rainy season. Thus, in the dry season, the monoculture also had a greater phyllochron in comparison with the other pasture systems. In the rainy season, no effect was observed of palm density on phyllochron $(\mathrm{P}<0.05)$. These results agree with our observations on LAR. Paciullo et al. (2008) found no differences in phyllochron with increasing degrees of shading over Urochloa decumbens pastures. However, these authors found an effect of season. Given better growth conditions, specifically air temperature and soil humidity, phyllochron was reduced.

During the rainy season, LER was higher only 
at the density of 131 palms.ha $^{-1}(\mathrm{P}<0.05)$. In the dry season, only the monoculture differed from the other systems with lowest LER (0.048 leaves.day ${ }^{-1}$. tiller $\left.^{-1}\right)$. In the comparison between seasons, only the two systems with highest densities had an increase in LER in the dry season. This finding is relevant because it indicates that silvopastoral systems may induce pasture growth in a period of relatively low food availability. Under lower irradiation grasses accelerate the growth of their photosynthetic apparatus. This pattern was also reported by Gobbi et al. (2011), who found a significant increase in the leaf blade of Urochloa decumbens cv. Basilisk, grown in shaded areas. The number of cell divisions along the central vein and the elongation of cells determines leaf length.

Table 3. Morphogenic characteristics of palisadegrass grown in monoculture or in combination with different densities of babassu palm.

\begin{tabular}{|c|c|c|c|}
\hline \multirow{3}{*}{$\begin{array}{l}\text { Palm density } \\
\text { palms.ha-1 }\end{array}$} & \multicolumn{2}{|c|}{ Season } & \multirow{3}{*}{$\mathrm{CV}(\%)$} \\
\hline & Rainy & Dry & \\
\hline & \multicolumn{2}{|c|}{ Leaf appearance rate (leaves.day ${ }^{-1}$.tiller $\left.{ }^{-1}\right)$} & \\
\hline monoculture & $0.057 \mathrm{Ab}$ & $0.048 \mathrm{Ab}$ & \multirow{4}{*}{29.37} \\
\hline 80 & $0.057 \mathrm{Ab}$ & $0.078 \mathrm{Aa}$ & \\
\hline 131 & $0.094 \mathrm{Aa}$ & $0.079 \mathrm{Aa}$ & \\
\hline \multirow[t]{2}{*}{160} & $0.062 \mathrm{Ab}$ & $0.062 \mathrm{Aa}$ & \\
\hline & \multicolumn{2}{|c|}{ Phyllochron (leaves.day ${ }^{-1}$.tiller ${ }^{-1}$ ) } & \\
\hline monoculture & $13.55 \mathrm{Ba}$ & $20.46 \mathrm{Aa}$ & \multirow{4}{*}{28.39} \\
\hline 80 & $12.75 \mathrm{Aa}$ & $12.24 \mathrm{Ab}$ & \\
\hline 131 & $12.53 \mathrm{Aa}$ & $10.28 \mathrm{Ab}$ & \\
\hline \multirow[t]{2}{*}{160} & $12.11 \mathrm{Aa}$ & $11.91 \mathrm{Ab}$ & \\
\hline & \multicolumn{2}{|c|}{ Leaf elongation rate $\left(\mathrm{cm}^{\left.- \text {day }^{-1}\right)}\right.$} & \\
\hline monoculture & $1.68 \mathrm{Ab}$ & $1.08 \mathrm{Ab}$ & \multirow{4}{*}{30.61} \\
\hline 80 & $1.33 \mathrm{Bb}$ & $2.69 \mathrm{Aa}$ & \\
\hline 131 & $2.74 \mathrm{Aa}$ & $2.70 \mathrm{Aa}$ & \\
\hline \multirow[t]{2}{*}{160} & $1.59 \mathrm{Bb}$ & $2.56 \mathrm{Aa}$ & \\
\hline & \multicolumn{2}{|c|}{ Leaf senescence rate $\left(\mathrm{cm}\right.$. day $\left.^{-1}\right)$} & \\
\hline monoculture & $0.73 \mathrm{Aa}$ & $0.54 \mathrm{Aa}$ & \multirow{4}{*}{44.14} \\
\hline 80 & $0.63 \mathrm{Aa}$ & $0.65 \mathrm{Aa}$ & \\
\hline 131 & $0.70 \mathrm{Aa}$ & $0.74 \mathrm{Aa}$ & \\
\hline \multirow[t]{2}{*}{160} & $0.70 \mathrm{Aa}$ & $0.70 \mathrm{Aa}$ & \\
\hline & \multicolumn{2}{|c|}{ Culm elongation rate $\left(\mathrm{cm}\right.$. day $\left.^{-1}\right)$} & \\
\hline monoculture & $0.16 \mathrm{Aa}$ & $0.09 \mathrm{Bb}$ & \multirow{4}{*}{34.86} \\
\hline 80 & $0.15 \mathrm{Aa}$ & $0.08 \mathrm{Bb}$ & \\
\hline 131 & $0.18 \mathrm{Aa}$ & $0.18 \mathrm{Aa}$ & \\
\hline 160 & $0.17 \mathrm{Aa}$ & $0.18 \mathrm{Aa}$ & \\
\hline
\end{tabular}

Means followed by the same uppercase/lowercase letters are not significantly different when in the same line/same column respectively, according to Duncan's test $(\mathrm{P}<0.05)$.

Season and palm density affected TER In the rainy season there were no differences in $(\mathrm{P}<0.05)$. TER was higher in the rainy season TER among pasture systems $(\mathrm{P}>0.05)$. In the compared to the dry season for all pasture systems. dry season, TER was almost twofold higher in 
the two systems with more palms per hectare in comparison with the monoculture and the system with 80 palms.ha ${ }^{-1}$. This pattern probably results from more favorable conditions under high palm densities, such as lower temperatures, higher soil humidity, and lower plant stress, as well as an increased competition for light. A similar response was found by Veras et al. (2010) while studying Andropogon grass in monocultures and in silvopastoral systems.
Leaf duration (LD) was not affected by season or system ( $\mathrm{P}>0.05$; Table 4$)$. Leaf senescence is a natural process that characterizes the last developmental stage of a leaf. After the complete expansion of the first leaves this process begins, and it becomes progressively more intense with the increases in LAI. The lack of changes in LD with increasing palm density may result from the deceleration of plant development under shaded areas, as previously mentioned.

Table 4. Structural characteristics of palisadegrass grown in monoculture or in combination with different densities of babassu palm.

\begin{tabular}{lccc}
\hline \multirow{2}{*}{$\begin{array}{c}\text { Palm density } \\
\text { palms.ha }\end{array}$} & \multicolumn{2}{c}{ Leaf duration (days) } & \multirow{2}{*}{ CV (\%) } \\
\cline { 2 - 3 } & \multicolumn{2}{c}{ Season } & \\
\cline { 2 - 3 } & Rainy & $16.77 \mathrm{Aa}$ & \\
\hline monoculture & $15.24 \mathrm{Aa}$ & $14.83 \mathrm{Aa}$ & 29.84 \\
80 & $12.61 \mathrm{Aa}$ & $13.64 \mathrm{Aa}$ & \\
131 & $15.98 \mathrm{Aa}$ & $13.72 \mathrm{Aa}$ & \\
160 & $11.96 \mathrm{Aa}$ & \multicolumn{2}{c}{ Final leaf length $(\mathrm{cm})$} \\
\hline & $14.95 \mathrm{Aab}$ & $13.57 \mathrm{Ab}$ \\
\hline monoculture & $14.54 \mathrm{Aab}$ & $17.06 \mathrm{Aab}$ & 24.90 \\
80 & $18.11 \mathrm{Aa}$ & $17.76 \mathrm{Aab}$ & \\
131 & $12.49 \mathrm{Bb}$ & $19.49 \mathrm{Aa}$ & \\
\hline
\end{tabular}

Means followed by the same uppercase/lowercase letters are not significantly different when in the same line/same column respectively, according to Duncan's test $(\mathrm{P}<0.05)$.

Season only had an effect on FLL in the highest palm-density system: a lower FLL was observed in the rainy season $(\mathrm{P}<0.05)$. When comparing among treatments in the rainy season, the lowest level of FLL was found in pastures with 160 palms.ha-1, which was similar to the levels observed in the system with 80 palms.ha ${ }^{-1}$ and in the grass monoculture. Pastures with 131 palms. $\mathrm{ha}^{-1}$ displayed the highest numerical level of FLL, which was statistically not different from the levels observed with 80 palms.ha ${ }^{-1}$ and with monoculture. In the dry season, the higher numerical value of FLL was obtained in the system with 160 palms. $\mathrm{ha}^{-1}$ which was statistically the same as observed in the systems with 131 and 80 palms.ha ${ }^{-1}$. These last two pastures had intermediate FLL values, which were statistically not different from the monoculture FLL.

In the rainy and dry seasons, the FLL values under the highest palm density were respectively $35,91 \%$ and $31.03 \%$ higher than in the grass monoculture.

\section{Conclusion}

The silvopastoral system with 80 palms.ha ${ }^{-1}$ favored agronomic features such as total forage, leaf and culm production. However, this same system 
promoted a reduction in the ratio of leaf to culm. The accumulation of dead material decreases with increasing palm densities.

Morphogenic characteristics including LAR, phyllochron, LER and TER were favored by increasing palm densities, especially during the dry season. Among the structural characteristics evaluated, FLL also increased with palm density.

\section{Acknowledgements}

The authors thank the Fundação de Amparo à Pesquisa e ao Desenvolvimento Científico e Tecnológico do Maranhão (FAPEMA), for financing the project and providing science initiation scholarships to our program, the Conselho Nacional de Pesquisa (CNPQ) for the scientific initiation scholarships, and to the FOPAMA study and research group for the help in conducting the experiments.

\section{References}

ALEXANDRINO, E.; VAZ, R. G. M. V.; SANTOS, A. C. S. Características da Brachiaria Brizantha cv. Marandu durante o seu estabelecimento submetida a diferentes doses de nitrogênio. Bioscience Journal, Uberlândia, v. 26, n. 6, p. 886-893, 2010.

CAMINHA, F. O.; SILVA, S. C.; PAIVA, A. J.; PEREIRA, L. E. T.; MESQUITA, P.; GUARDA, V. D. Estabilidade da população de perfilhos de capim-marandu sob lotação contínua e adubação nitrogenada. Pesquisa Agropecuária Brasileira, Brasília, v. 45, n. 2, p. 213-220, 2010.

CÂNDIDO, M. J. D.; ALEXANDRINO, E.; GOMIDE, J. A. Duração do período de descanso e crescimento do dossel de Panicum maximum cv. Mombaça sob lotação intermitente. Revista Brasileira de Zootecnia, Viçosa, MG, v. 34, n. 2, p. 398-405, 2005.

CHAPMAN, D.F.; LEMAIRE, G. Morphogenetic and structural determinants of plant regrowth. In: BAKER, M. J. (Ed.). Grasslands for our world. Wellington: SIR Publ., p. 55-64. 1993.

EMPRESA BRASILEIRA DE PESQUISA AGROPECUÁRIA - EMBRAPA. Boas práticas agropecuárias: bovinos de corte: manual de orientações. 2 . ed. Campo Grande: Embrapa Gado de Corte, 2011. 69 p.
Sistemas silvipastoris. Colombo: Embrapa Floresta, 2013. Disponível em: <http://www.cnpf. embrapa.br/pesquisa/safs/index.htm>. Acesso em: 15 nov. 2014.

FELDHAKE, C. M. Microclimate of a natural pasture under planted Robinia pseudoacacia in central Appalachia, West Virginia. Agroforestry Systems, Columbia, v. 53, n. 3, p. 297-303, 2001.

GOBBI, K. F.; GARCIA, R.; VENTRELLA, M. C.; GARCEZ NETO, A. F.; ROCHA, G. C. Área foliar específica e anatomia foliar quantitativa do capimbraquiária e do amendoim-forrageiro submetidos a sombreamento. Revista Brasileira de Zootecnia, Viçosa, MG, v. 40, n. 7, p. 1436-1444, 2011.

INFOSTAT. Software estatistico. Versión 2004. Córdoba: Universidad Nacional de Córdoba, 2004.

INSTITUTO NACIONAL DE METEOROLOGIA INMET. Gráficos climatológicos. Brasília: dados on line, 2013. Disponível em <http://www.inmet.gov.br/ sonabra/maps/pg_automaticas.php $>$. Acesso em: 20 dez. 2014.

LEMAIRE, G.; CHAPMAN, D. Tissue flows in grazed plant communities. In: HODGSON, J.; ILLIUS, A. W. (Ed.). The ecology and management of grazing systems. Wallingford: Cab International, p. 3-36, 1996.

PACIULlO, D. S. C.; CAMPOS, N. R.; GOMIDE, C. A. M.; CASTRO, C. R. T. de; TAVELA, R. C.; ROSSIELLO, R. O. P. Crescimento de capim-braquiária influenciado pelo grau de sombreamento e pela estação do ano. Pesquisa Agropecuária Brasileira, Brasília, v. 43, n. 7, p. 917-923, 2008

PACIULlO, D. S. C.; CARVALHO, C. A. B.; AROEIRA, L. J. M.; MORENZ, M. F.; LOPES, F. C. F.; ROSSIELLO, R. O. P. Morfofisiologia e valor nutritivo do capim-braquiária sob sombreamento natural e a sol pleno. Pesquisa Agropecuária Brasileira, Brasília, v. 42, n. 4, p. 573-579, 2007.

PEREIRA, A. C.; ALMEIDA, J. C. C.; MOREIRA, T. G. B.; ZANELLA, P. G.; CARVALHO, C. A. B.; MORAIS, L. F.; SOARES, F. A.; LIMA, M. A. Avaliação do componente arbóreo e forrageiro de sistemas silvipastoris na mesorregião dos campos das vertentes de Minas Gerais. Revista Brasileira de Agropecuária Sustentável, Viçosa, MG, v. 5, n. 1, p. 66-77, 2015.

RODRIGUES, C. O. D.; ARAÚJO, S. A. C.; VIANA, M. C. M.; ROCHA, N. S.; BRAZ, T. G. S.; VILLELA, S. D. J. Light relations and performance of signal grass in silvopastoral system. Acta Scientiarum. Animal Sciences, Maringá, v. 36, n. 2, p. 129-136, 2014. 
SOUSA, L. F.; MAURÍCIO, R. M.; MOREIRA, G. R.; GONÇALVES, L. C.; BORGES, I.; PEREIRA, L. G. R. Nutritional evaluation of Braquiarão grass in association with Aroeira trees in a silvopastoral system. Agroforestry Systems, Cham, v. 79, n. 2, p. 189-199, 2010.
VERAS, V. S.; OLIVEIRA, M. E.; LACERDA, T. M. S. B.; CARVAlHO, B.; AlVES, A. A. Produção de biomassa e estrutura do pasto de capim-Andropogon em sistema silvipastoril e monocultura. Arquivo Brasileiro de Medicina Veterinária e Zootecnia, Belo Horizonte, v. 62, n. 1, p. 200-207, 2010. 
